\title{
Pension Reforms in Commonwealth of Independent States Countries
}

\section{Lusine Karapetyan, $P h D^{1}$}

\begin{abstract}
The study aims to observe the pension systems and directions of pension reforms in the 10 member countries of commonwealth independent. Replacement rates for the countries preserving distributive pension system, gross replacement rates amongst countries that introduced cumulative components, average replacement rates, the average index of pension system load, life expectancy at birth, and natural increase in Commonwealth of Independent States (CIS) countrieshave been critically examined. Secondary data of above area have been used for 2000-2016 for 10 countries. Data were obtained from statistical book. Descriptive tools viz mean, standard deviation, growth and trend have been used analyse the data.
\end{abstract}

The study reveals amongst the countries which preserved the distributive pension system the highest indicator was registered in Belarus (41\%), and the lowest was found in Moldova (25\%). Armenia had the lowest gross replacement rate (21\%) in 2016 while highest indicator was registered in Kazakhstan (38\%). All CIS countries except Tajikistan encountered with demographic aging issue. The increase in the number of pensioners in CIS countries resulted in the overload of the employed population, countries with cumulative components, the burden is higher for Armenia it was 2.2 and 1.8 for Russia.only five countries did not encounter natural growth issues amongst the CIS countries in 2016. In Tajikistan the natural growth formed $25 \%$ (promile), which is 1.7 times higher rate compared to 2000.

Key words: Pension, Retirement Age, Senility, Cumulative Elements, Commonwealth of Independent States (CIS)

JEL classification: H55, J26, J32

\section{Introduction}

Social-economical fundamental changes in CIS countries at the end of the $20^{\text {th }}$ century had important impact on different spheres of social life including pension systems that

1 Associate Professor, Chair, Labor Economics, Armenian State University of Economics, Email: L-Karapetyan@hotmail.com 
act on the principle of generation solidarity. Economic drops, financial crisis evoking in separate countries or regions inevitably acquire global universal essence and no country can solve social-financial issues that they face without adjusting and coordinating its national policy with policies implemented by other countries.Global social risks impact on elderly people's living standards which provide the necessity of having effective pension security system.

Distributive pension system is effective to be used only in those countries where stable economic growth exists. Almost all the countries which have implemented pension amendments had had classic distributive pension system/pay-as-you-go/long before the appearance of demographic, financial, economical, social and other core problems. However, today pension amendments take place not only in the CIS countries but also in a number of different countries around the world as a result of the rise in the average life expectancy, reduction of the working population, lack of financial means in distributive pension systems, growth of elderly people's ratio in the population, pension's amount, the necessity to create immediate link between pension, salary and social payments and long-term financial stability of the pension system. In the CIS countries these issues have rather deep roots.

The study aims to observe the pension systems and directions of pension reforms in the CIS countries, as well as to bring out issues that exist in the system. In order to implement the given aim the solutions of the following issues are of importance: to study the peculiarities of each country's pension system, to carry out an analysis of factors that impact on pension system, to represent the necessity of investment and continuous improvement of multi-pillar pension systems.

\section{Literature Review}

The main motivation for the countries that have carried out pension reforms is the expectation that pension funds will play a dynamic role in the development of the capital marketas far as pensioners make long-term savings in the mandatory cumulative pension component, it is expected that pension funds (in contrast with other institutions) will be able to provide long-term financial resource offers both for their native corporations and the government (Torre \&Schmukler, 2007). In contrast with other institutional investors, pension funds are considered to be institutions which have maximum investments in the development of the native capital markets (Raddatz\&Schmukler, 2008). Nowadays it is still debatable what influence the pension funds have on the development of the capital markets and whether pension amendments will provide the pensioners with the long-awaited result.Some authors (Catala'n, 2004; Murphy \&Musalem, 2004) insist that pension funds contribute to the development of the native capital markets. Besides, the creation of the new financial tools and diversification of investment portfolio contribute to the reduction of the risks in the cumulative pension component (Mauricio, 2007). If we take into consideration the widespread viewpoint that financial stability has positive 
association with economic growth, pension funds can stimulate that growth.While in the study by Yermo (2005) pension funds do not contribute to the development of capital markets yet, as far as pensioners' savings are not invested in an optimal way and the transition to the private pension system itself does not result in the elimination of political risks. From this point of view the way of pension system management is not important, but the quality of institutional and macroeconomic environment of that country is of importance. In the study by Barr (2002), cumulative pension systems face the same problems as distributive ones. The only difference is that in the first case possible bad news can be related to market mechanisms and not to political decisions.

\subsection{Review of Pension Systems in CIS Countries}

\subsubsection{Republic of Armenia:}

On December 22, 2010 Republic of Armenia adopted the legal package regulating the multipillar pension system, which included the five laws: laws on "State pensions", "Cumulative pensions", "Income tax and embodied registration of mandatory cumulative payment", "Investment funds" and "Income tax". The aim of new pension system is to create insurance mechanisms, that will allow to strengthen the responsibility of the employee towards his future pension and link the pension to the real labour investment. It is the lack of this link that was considered to be the "weak" point of the distributive pension system. Armenian pension system is attached to the existing distributive system, which has been supplemented with two new degrees: mandatory and cumulative ${ }^{2}$.

Multi-pillar pension system provides three types of pension. These are social aid, cumulative pension and volunteer cumulative pension. Social aid is for those who have not worked in their life or have worked for less than ten years (is called 0 degree), second is first degree or labour pension which is designed for paying the pension to those who were born before 1974. The labour pension in this degree will consist of two parts- the basic pension and sum paid for work experience. The third pillar is second degree or cumulative pensionto those who were born after January 1, 1974. Pension paid in the second degree will be formed as a result of payment made by the person during his working life and donations by the government. The participants will be allowed to get stable pension for the united taxes paid by them, as well as corresponding compensation for work experience until moving to the cumulative degree. The third degree or voluntary cumulative pension is designed for those who want to participate in various pension cumulative schemes suggested by voluntary financial institutions (insurance companies or pension funds) to get extra pensions.Since 2011 the age for labour pension for both sex is equal i.e. 63 years old with at least 25 years of work experience.

2 http://www.ssss.am/arm/pension-reforms/projects/ [Feb 2, 2018] 


\subsubsection{Republic of Azerbayjan}

The law on "Labour pensions" was enforcedin2006.Man and womanhaving age at least 63 and 60 respectively and at least 12 years of work experience are eligible to get age pension ${ }^{3}$. Some basic problems while implementing the pension systems are to provide reliable social security, long-term stability of pension system, just principle of appointing pension and balance of incomes and expenditures in the pension system.However, global economic crisis and demographic changes have their influence on the implementation of the above-mentioned issues. Taking into account the existing challenges they had to gradually increase retirement age in this country as well. The retirement age started to increase by six months each year and the retirement age will become 65 for man and women in 2021 and 2027 respectively which was effective from July 1, 2017

\subsubsection{Belarus}

The right to state pension in Belarus is regulated by the law on "Pension Security" and other normative acts. Contemporary Belarus has adopted its pension system form USSR and has made very few changes in the system so far.It has state distributive pension system based on the principle of generation solidarity. In Belarus the amount of the pension is influenced by the work experience and the amount of salary from which social donations are made.There is no mandatory cumulative pension component.Till 201760 years old men with at least 25 years' work experience and 55 years old women with at least 20 years' work experience have the right to receive age pension on general basis. But as a result of new legislative changes since the January 1 in 2017 the retirement age will be gradually raised by six months each year as a result the retirement age for women will reach 58 and 63 for men in $2022^{4}$.

\subsubsection{Kazakasthan}

In Kazakhstan, unlike the countries that have advanced market economy, the introduction of the pension accumulative component meant to create financial institutions. Three components were included in the pension system viz.a) the state pension component of solidarity, it provides pensions to pensioners and those workers whose pension rights have accumulated in the pension system, b) the second one is the mandatory private pension component.Mandatory pension contributions are accumulated in individual retirement accounts, and c) the third component includes voluntary pension contributions. Thus, in 2017, the 20th anniversary of Kazakhstan's pension system reform is underway, with a gradual transition from a solidarity-based distributive system to a system based on the principle of individual retirement savings.The retirement age for men is 63 and 58

3 http://apsf.ru/Izdaniya/Vestnik_MAPSF_2017(19).pdf, pp 11-12). [Feb 2, 2018]

4 http://soczaschita-volkovysk.gov.by/index.php/ru/otdel-pensij-i-posobij/dokumenta tsiya/555-zakon-o-pensionnom-obespechenii-ot-13-yanvarya-2017-goda.

$44 \sim$ Nepalese Journal of Insurance and Social Security 
for women, but starting from January 1, 2018, it will increase every year by six months leveling off to the men's retirement age ${ }^{5}$.

\subsubsection{Kyrgyzstan}

Kyrgyzstan has implemented reforms in the pension system for already 25 years. Simultaneously with current pension accounts from January 1, 2010, the cumulative component was introduced at the rate of $2 \%$ of the employee's salary. Following the introduction of the cumulative component, Kyrgyzstan's pension system consists of three components: pension component of state compulsory solidarity, mandatory funded component and voluntary individual accumulative component.As a result of legislative changes in 2014, the cumulative component becomes mandatory for all citizens.The retirement age for men is 63 years, with at least 25 years of work experience, and 58 for women with 20 years' work experience. Pension appointment, payment and supervision over them is carried out by the Social Fund ${ }^{6}$.

\subsubsection{Moldova}

In Moldova, citizens' right to pension is regulated by the law on "State Pension System" and other legal acts.According to the changes made in 2016 having been enforced since 2017, the money donated for insurance,carried out during the working activity, is considered to be the basis for defining the amount of pension. The formula for calculating the pension has been changed, the necessary work experience and retirement age for appointing pension is also being gradually increased.The law has also defined the notion of the highest pension, the amount of which cannot exceed the fivefold of the average salary in the country.If the annual consumer price index in the country does not exceed $2 \%$, the pension index is not implemented.From 2017 the retirement age will rise by 4 months for men and by 6 months for women. Currently it is 62 years and 4 months for men and 57 for women. From 2019 the retirement age will be 63 for men and starting from 2028, the retirement age for women will become equal to the men's age. Since 2018, the length of required work experience for men to get age pension ismeant to be 34 years which is set 31 years for women, which will therefore rise by 6 months and reach 34 in $2024^{7}$.

\subsubsection{The Russian Federation}

Since 1992 non-governmental pension funds have been operating in the Russian Federation, whose activities were regulated only in 1998, when the Law on Non-State Pension Funds was adopted. The new phase of pension reform in Russia began in 2002. The main goal of these reforms was the acquisition of long-term financial balance of the pension system and the formation of a stable source of additional revenues for

5 http://egov.kz/cms/ru/articles/pensionnaya_sistema).

6 http://socfond.kg/ru/citizens/9-Struktura-piensionnoi-sistiemy-KR.html ).

7 http://pensionreform.ru/59709). 
investment in the pension system. With these reforms, a transition from distributive pension system to distributive-cumulative system was made. The cumulative part of the working pension was formed in 1967 and for the citizens born after that. Since 2002, the state working pension of the citizens is formed in the mandatory pension insurance system and consists of 3 parts: basic, insurance and cumulative. From January 1, 2004, Russian citizens received the opportunity to transfer their cumulative pension to nonstate pension funds. In 2017, the minimum work experience required for the retirement pension is 8 years, which will gradually rise to 15 from 2024, and the retirement age is 60 for men and 55 for women ${ }^{8}$

\subsubsection{Tajikistan:}

The pension reform in the Republic of Tajikistan has been implemented in four stages. In first stage, a personalized accounting system has been introduced since January 1 , 1999. In second stage i.e. from July 1, 2009, first accumulative payments have been implemented. Law on Insurance and State Pensions began to be partially applied from January 1, 2013. The fourth stage was started from January 1, 2017 that all types of pensions in the republic are assigned and paid under the Law on Insurance and State Pensions.In 2000 changes in socio-economic relations have led to radical reforms in the pension system, with the aim of fully reducing the size of the pension to individual citizens' contributions and, in some cases, from the social security budget in Tajikistan. In 1994, the Law on Citizens' Retirement Benefit has been effective until January 1, 2017.

According to the new law, men need to have at least 300 months of insurance coverage, and the retirement age is 63 years, and 58 for women and at least 240 months of insurance coverage. However, a person may be assigned a partial retirement pension if he has at least 60 months of insurance experience. ${ }^{9}$

\subsubsection{Turkmenistan}

In 2012, the Law on State Pension Insurance, adopted in Turkmenistan, introduced a contingent pension system.Contract payment accounts are used to fund current retirees' pensions. The pension fund functions in the new pension system for collecting, distributing, controlling, maintaining personal accounts, appointing and paying pensions. The cumulative pension component has a voluntary nature.Men over the age of 62 and women over 57 have the right to pension if they have at least 5 years of insurance experience. Pension capital depends on the years of the citizen's employment, the size of the salary and the expected average life expectancy ${ }^{10}$.

8 (Retrieved from http://www.pfrf.ru/grazdanam/pensions/kak_form_bud_pens/)

9 http://nafaka.tj/ru/qonunho/qonun-19-03-2013-955, http://nafaka.tj/ru/qonunho/qonun12-01-2010-595).

10 http://turkmenistan.gov.tm/?id=2752 ).

$46 \sim$ Nepalese Journal of Insurance and Social Security 
2.1.10Ukrine:In Ukraine, Law on Universal Mandatory State Pension Insurance stipulated three levels of the pension system in 2003. In first level, mandatory state pension insurance based on solidarity principle was applied, in second level, mandatory cumulative pension insurance and in third level non-state pension security based on volunteerism principle was implemented.

The Pension Assignment and Payment function is implemented by the Pension Fund. The right to age pension is defined for at least 15 years of insurance coverage, with the retirement age of men being 60, which was 55 for women in 2011, but the government gradually increases the retirement age, and the retirement age for women will be equal to men starting 2021. However, pension reform is not ending up so now changes are envisaged in the law and if it is accepted, the minimum age for retirement benefits from 2018 will gradually increase from 15 to 25 years, and to 35 starting 2028 . Actually, these changes envisage increasing the retirement age, as long as the person does not have an insurance experience, the person will have to work longer to earn the age pension rights. Investment of the mandatory accumulative components was delayed until $1^{\text {st }}$ of January 2019 in Ukraine ${ }^{11}$.

2.1.11 Uzbekistan:Uzbekistan, unlike other CIS countries, is distinguished by positive trends in the demographic structure of the population, which allows more optimal reforms in the pension system. The Law on Citizens' State Pension Security enforced in 1993 significantly improved the pension system, bolstered the principle of social justice, contributed to the increase of material welfare of the pensioners. However, in the course of these years changes and additions have been made to the law in order to improve the pension system. In 2004, along with other CIS countries, Uzbekistan, adopted a law on mandatory pension accumulation for citizens, which also established a non-state pension security. Starting from 2005, 1\% of workers' salaries are directed to individual accounts. 60 years old men with at least 25 years of experience and 55 years old women having at least 20 years of experience have the right to get age pension. People who have at least 7 years of work experience are eligible for a partial retirement pension, and in case of a lower age, a person is entitled to an age benefit. Thus, Uzbekistan's current pension system includes both distributive and accumulative elements ${ }^{12}$.

\section{Methodology}

The information of this study was obtained through various secondary sources like statistic reports, websites and articles. Variables of the study are replacement rates for the countries preserving distributive pension system, gross replacement rates amongst countries that introduced cumulative components, average replacement rates, the average index of pension system load, life expectancy at birth, and natural increase in CIS

11 http://www.pfu.gov.ua/pfu/control/uk/index

$12 \mathrm{http}: / /$ lex.uz/pages/GetAct.aspx?lact_id=112312 
countries. The mentioned statistical data are taken from the official statistics yearbooks and reports of CIS countries. Secondary data of above area have been used for the period of 1992-2016 and 2005-2016 for 10 countries. Data were obtained from statistical book. Descriptive tools viz mean, standard deviation, growth and trend have been used analyse the data.

\section{Result and Discussion}

The CIS countries have implemented pension system reforms and continue to develop the system, trying to overcome the deepening gap between financial stability and maintenance of pension system equivalence. Replacement rate decides degree of pension system equivalence in any country. This is revealed through the ratio between average pensions and average nominal wages.

\subsection{Gross Replacement Rates for the Countries Preserving Distributive Pension}

According to the International Labor Organization (ILO), the replacement rate for each country must be not lower than $40 \%{ }^{13}$. Despite the demographic and financial issues, Azerbaijan, Moldova, Belarus and Ukraine continue to maintain the distributive pension systems, but Armenia, Kazakhstan, Kyrgyzstan, Russia, Tajikistan and Uzbekistan introduced cumulative components. The dynamics of gross replacement rates for the CIS countries are shown in Figure 1.

Figure1. Gross Replacement Rates for the Countries Preserving Distributive Pension System in 2000-2016

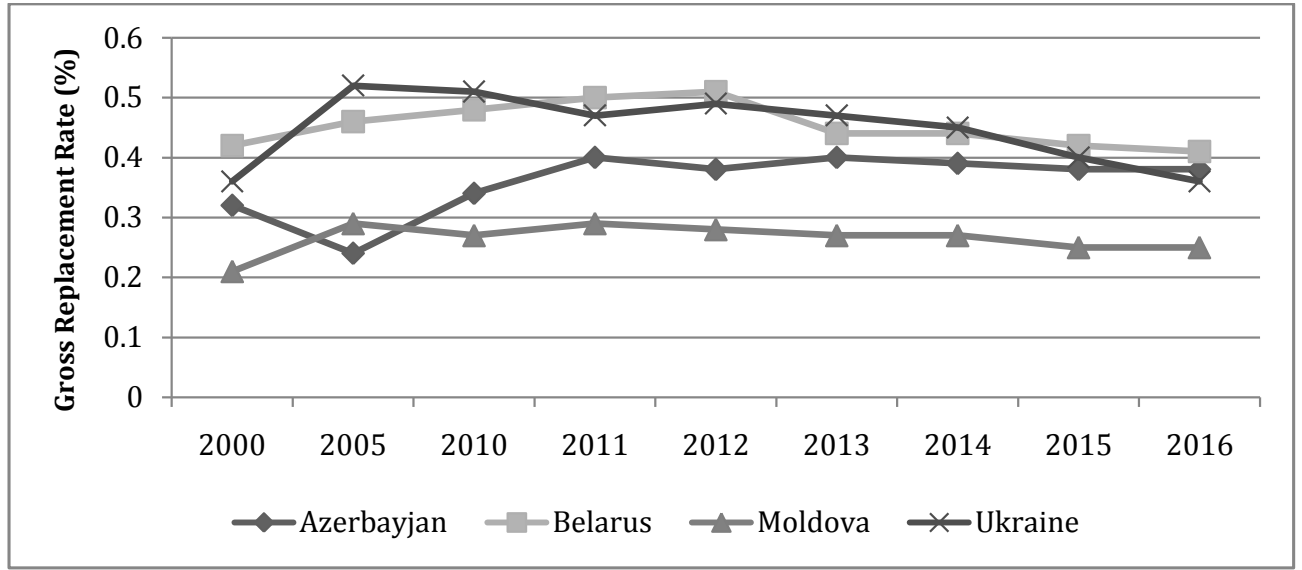

Source: CIS countries' statistical data: 2000-2016

13 http://www.ilo.org/dyn/normlex/en/f?p=NORMLEXPUB:12100:0::NO::P12100_ INSTRUMENT_ID:312247.

$48 \sim$ Nepalese Journal of Insurance and Social Security 
Amongst the countries which preserved the distributive pension system the highest indicator was registered in Belarus (41\%), and the lowest was found in Moldova (25\%). The highest rate documented in Ukraine was in 2005 (52\%). However, as shown in the figure the number decreased throughout time. So, in Ukraine, in 2016 the gross replacement rate decreased by 16 percentage points forming 36\%. The indicator in Azerbaijan was $24 \%$ in 2005, however in 2010 it increased by 10 percentage points and formed 38\% in 2016.

\subsection{Gross Replacement Rates amongst Countries that Introduced Cumulative Components}

Gross replacement rates amongst countries that introduced cumulative components has been exhibited in Figure 2.

Figure 2: Gross Replacement Rates amongst Countries that Introduced Cumulative Components in 2000-2016.

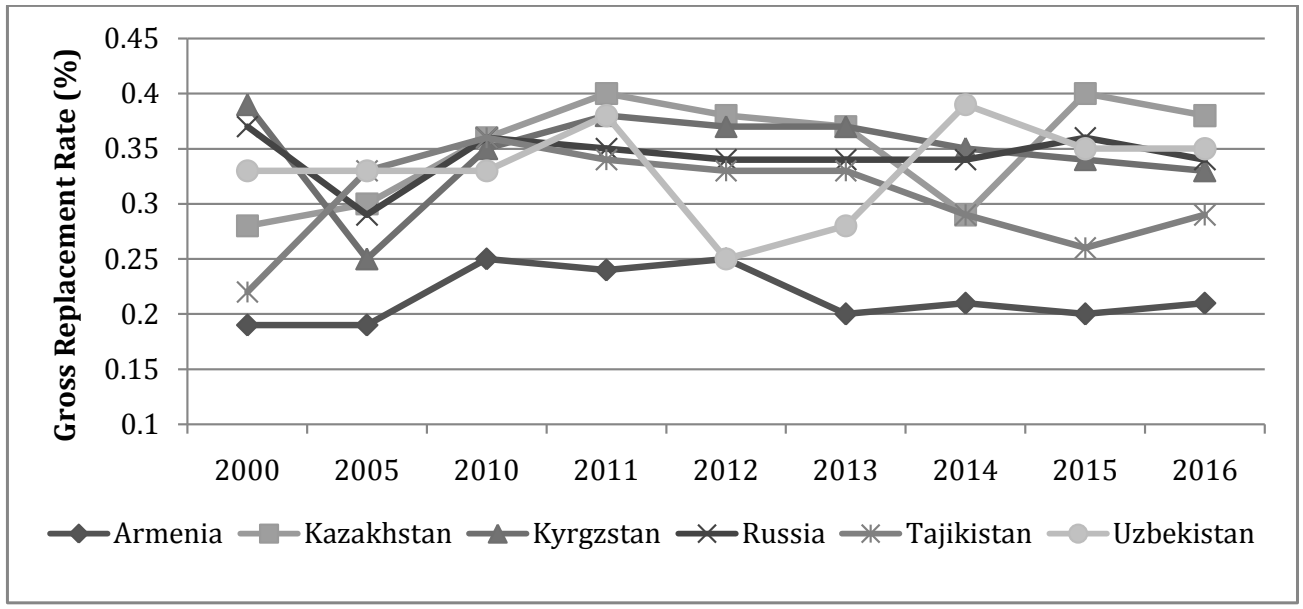

Source: CIS countries' statistical data 2000-2016

Figure 2 showed that Armenia had the lowest gross replacement rate 2016 (21\%) while highest indicator was registered in Kazakhstan (38\%). The lowest indicator in Uzbekistan was documented in 2012 (25\%). In 2013 the latter increased by 3 percentage points. Moreover in 2014 it increased by 11 percentage points and formed 39\%. Later, in 2016 the indicator decreased by 4 percentage points and formed 35\%. The gross replacement rate was 29\% in Tajikistan in 2016, which increased from by 7 percentage points.In Russian Federation, the average replacement rate was 34.7\% in 2010-2016. In Kyrgyzstan the rate was $35.6 \%$. 


\subsection{Average Replacement Rates in the CIS Countries}

Average replacement rates in CIS countries during 2000-2016 has been presented in Figure 3.

Figure 3 :Average Replacement Rates in the CIS Countries in 2000-2016

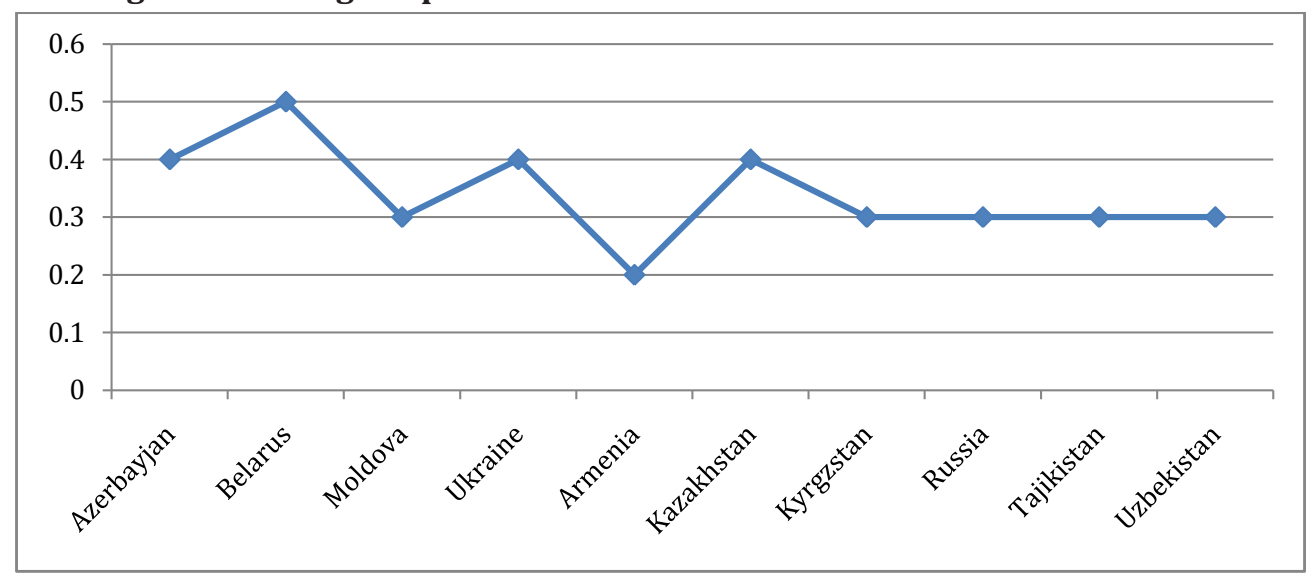

Source: CIS countries' statistical data 2000-2016

Figure 3 shows thatamong the countries which preserved the distributive pension system the highest indicator was registered in Belarus (50\%), and the lowest in Moldova (30\%). Among the countries that have introduced the mandatory cumulative component, the highest replacement rate was registered in Kazakhstan (40\%), and the lowest in Armenia (20\%). Consequently, all CIS countries except Tajikistan encounter with demographic aging issue.The increase in the number of pensioners in CIS countries resulted in the overload of the employed population. The second most important indicator for 19922016 is the ratio between the number of employed people and the number of pensioners. The indicator of the pension system load of the CIS countries is presented in Annex 2 and it shows that in 2016 only in Azerbaijan 3.6 employed is equal to 1 pensioner. In the rest 3 countries the indicator is 1.7 Belarus, 1.8 Moldova, 1.4 Ukraine. In 20161 pensionerwas equal to 4.3 employed in Uzbekistan, 3,8 employed in Kyrgyzstan, 3.7 in Tajikistan and 3.1 in Kazakhstan, whereas in Armenia and Russia this index was 1.9 and 1.7 respectively, so out of 6 countries only the results of 4 countries are optimistic. It should be noted that this ratio should be at least 3:1 for the financial stability of the pension system, but if we take into account that the legislation on employment of CIS countries has categorized that are considered to be occupied, but are exempt from paying social benefits, the financial stability of the pension system becomes more pessimistic, since the load factor is actually in the range between 1 to 1.1 . In order to make the situation more realistic it is necessary to take the proportion of performers and pensioners that make the actual social payment, but we have presented the calculation by the number of the employed since we did not have the data released.

$50 \sim$ Nepalese Journal of Insurance and Social Security 


\subsection{The Average Index of Pension System Load in CIS Countries}

The average index of pension system load in CIS countries during 1992-2016 has been presented in Figure 4.

Figure 4: The average Index of Pension System Load in CIS Countries in 1992-2016

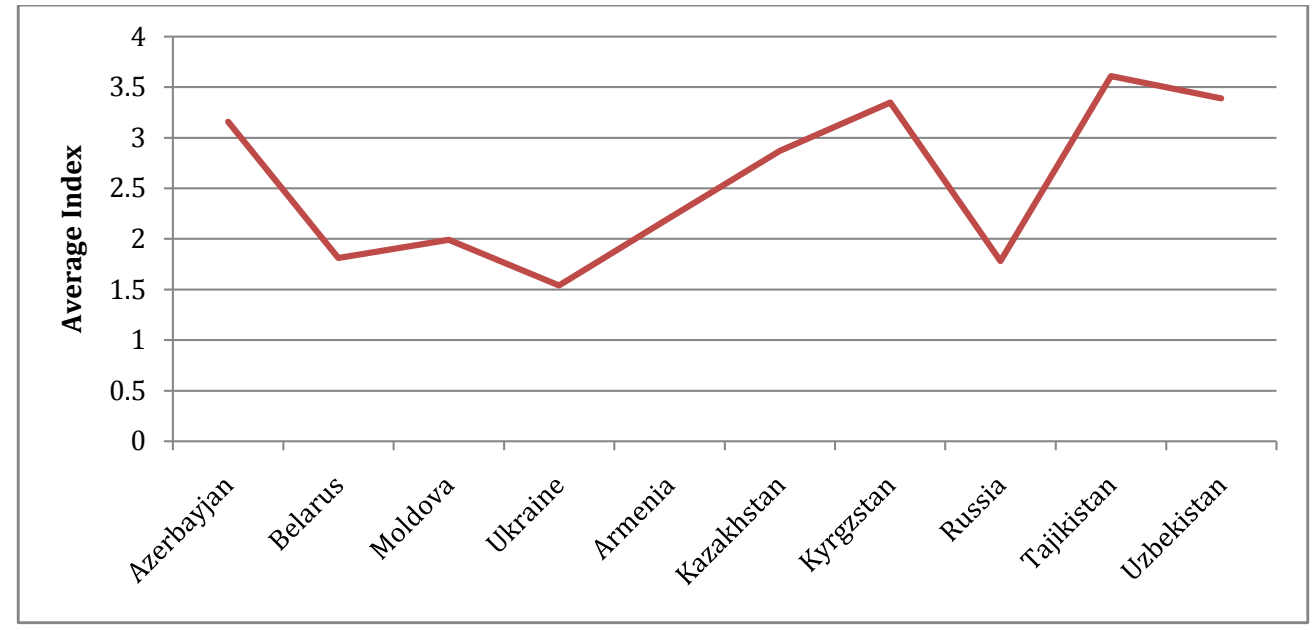

Source: CIS countries' statistical data 2000-2016

Figure 4 shows that the average index of pension system load in 1992-2016 was 3,2 in Azerbaijan, 1.8 in Belarus, 2 in Moldova, 1.6 in Ukraine. The countries which preserved distributive pension system the load factor compared to the countries with accumulative component, except Azerbaijan, pension load is redistributed among less number of the employed population. This in its turn predetermines the deterioration of the pension system load ratio. But in countries with cumulative components, the burden is higher for Armenia it was 2.2 and 1.8 for Russia.

\subsection{Life Expectancy at Birth in CIS Countries}

Life expectancy does matter in pension liability of the country. Higher life expectancy increases the financial burden of the countries with distributive pension systems. The research also studied the life expectancy at birth in CIS countries from 2005 to 2016. Life expectancy in CIS countries has been presented in Table 1. 
Table 1: The Life Expectancy at Birth in CIS Countries (2005- 2016)

Figure in years

\begin{tabular}{lccccccccccccc}
\hline Country & $\mathbf{2 0 0 5}$ & $\mathbf{2 0 0 6}$ & $\mathbf{2 0 0 7}$ & $\mathbf{2 0 0 8}$ & $\mathbf{2 0 0 9}$ & $\mathbf{2 0 1 0}$ & $\mathbf{2 0 1 1}$ & $\mathbf{2 0 1 2}$ & $\mathbf{2 0 1 3}$ & $\mathbf{2 0 1 4}$ & $\mathbf{2 0 1 5}$ & $\mathbf{2 0 1 6}$ & $\begin{array}{c}\text { Growth } \\
\text { (\%) }\end{array}$ \\
\hline Armenia & 73.5 & 73.3 & 73 & 74 & 74 & 74 & 74 & 74.3 & 75 & 75 & 75 & 75 & 2.0 \\
Azerbaijan & 72.4 & 72 & 73 & 72 & 72 & 72 & 74 & 74 & 74 & 74 & 74 & 74.5 & 2.9 \\
Belarus & 68.8 & 69 & 70 & 70 & 70 & 70 & 71 & 70 & 72 & 73 & 73 & 73 & 6.1 \\
Kazakhstan & 65.9 & 66 & 67 & 66 & 67 & 69 & 69 & 69 & 69 & 70 & 70 & 72.5 & 10.0 \\
Kirgizstan & 67.9 & 68 & 66 & 66 & 68 & 68 & 69 & 69 & 70 & 70 & 70 & 70.5 & 3.8 \\
Moldova & 67.9 & 68 & 69 & 64 & 69 & 70 & 69 & 69 & 71 & 72 & 72 & 72 & 6.0 \\
Russia & 65.3 & 66 & 66 & 67 & 68 & 68 & 69 & 69 & 70 & 71 & 71 & 71.5 & 9.5 \\
Tajikistan & 63 & 63 & 64 & 67 & 67 & 67 & 72 & 73 & 67 & 67 & 67 & 69.5 & 10.3 \\
Ukraine & 68 & 68 & 68 & 68 & 68 & 68 & 69 & 70 & 71 & 71 & 71 & 71 & 4.4 \\
Uzbekistan & 67 & 67 & 67 & 67 & 68 & 68 & 70 & 68 & 68 & 68 & 68 & 73.5 & 9.7 \\
\hline Mean & 67.97 & 68.03 & 68.3 & 68.1 & 69.1 & 69.4 & 70.6 & 70.53 & 70.7 & 71.1 & 71.1 & 72.3 & 6.4 \\
SD & 2.966 & 2.812 & 2.83 & 2.879 & 2.166 & 2.059 & 1.96 & 2.206 & 2.369 & 2.385 & 2.385 & 1.661 & \\
\hline
\end{tabular}

Source: CIS countries' statistical data

SD: Standard Deviation, Growth on 2016 over 2005

In 2016, the highest average life expectancy rates were registered in Armenia (75 years) followed by Azerbaijan (74.5) and Belarus (73) and the lowest in Tajikistan (69.5). Over the study period, the life expectancy of Tajikistan increased highest (10.3\%) while Armenia lowest (2\%). The average growth has been found 6.4 percent. The life expectancy among the countries in 2005 varied most $(\mathrm{SD}=2.9)$ and in 2016 varied least $(S D=1.7)$ which showed that the difference on life expectancy among the countries is gradually lowered.

\subsection{Natural increase in CIS Countries}

The another significant indicator that influence the pension system is coefficient of natural increase, since the latter has its influence on the implementation of reforms of pension system as well. Natural increase is the difference between live births and deaths in a certain year. The natural increase of CIS countries per 1000 population over 20002016 has been elucidated in Table 2 .

$52 \sim$ Nepalese Journal of Insurance and Social Security 
Table 2: Natural increase in CIS Countries in 2000-2016 (per 1,000 population)

\begin{tabular}{|c|c|c|c|c|c|c|c|c|c|c|}
\hline Year & 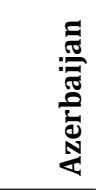 & $\frac{\mathscr{J}}{\bar{d}}$ & $\frac{\pi}{\frac{0}{2}}$ & 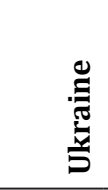 & 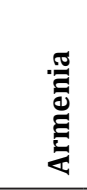 & 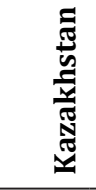 & 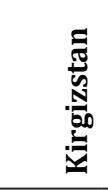 & 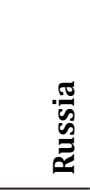 & 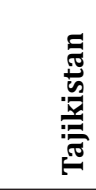 & 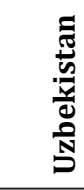 \\
\hline 2000 & 8.9 & -4.1 & -1.1 & -7.5 & 2.7 & 4.6 & 12.8 & -6.7 & 15.1 & 17 \\
\hline 2001 & 8.1 & -4.9 & -1 & -7.6 & 2.5 & 4.8 & 13.2 & -6.5 & 22.1 & 15.1 \\
\hline 2002 & 8 & -5.9 & -1.7 & -7.6 & 2.1 & 5.3 & 13.1 & -6.5 & 21.4 & 15.1 \\
\hline 2003 & 8 & -5.5 & -1.8 & -7.5 & 3.1 & 6.2 & 13.8 & -6.2 & 22 & 15.5 \\
\hline 2004 & 10 & -5.2 & -1 & -7.5 & 3.7 & 8.1 & 14.7 & -5.6 & 22.4 & 15.5 \\
\hline 2005 & 10 & 0.8 & -2 & -7 & 5 & 6 & 13 & -6 & 23 & 16 \\
\hline 2006 & 11.6 & -4.3 & -1.5 & -7 & 3.2 & 9.4 & 15.9 & -4.8 & 23 & 15.5 \\
\hline 2007 & 12 & -5 & -1 & -6.4 & 4.1 & 10 & 16 & -5 & 19 & 17 \\
\hline 2008 & 12 & -3 & -1 & -6 & 4.2 & 11 & 17 & -3 & 22 & 17 \\
\hline 2009 & 12 & -3 & -1 & -6 & 5.2 & 13 & 17 & -3 & 23 & 18 \\
\hline 2010 & 11 & -2 & -1 & -5 & 5.2 & 17 & 17 & -2 & 24 & 18 \\
\hline 2011 & 11 & -2 & -4 & -4 & 4.7 & 14 & 19 & -1 & 24 & 19 \\
\hline 2012 & 13 & -3 & 0 & -4 & 4.9 & 14 & 20 & -1 & 23 & 18 \\
\hline 2013 & 13 & -1 & 0 & -4 & 4 & 15 & 20 & 0 & 25 & 16 \\
\hline 2014 & 12 & 0 & 0 & -4 & 5.1 & 15 & 21 & 0 & 27 & 17 \\
\hline 2015 & 12 & 0 & 0 & -4 & 4.6 & 17 & 21 & 0 & 26 & 18 \\
\hline 2016 & 11 & 0 & 0 & -4 & 4.1 & 15 & 22 & 0 & 25 & 18 \\
\hline Growth(\%0) & 1.24 & 0.00 & 0.00 & 0.53 & 1.52 & 3.26 & 1.72 & 0.00 & 1.66 & 1.06 \\
\hline
\end{tabular}

Source: CIS countries' statistical data in 2000-2016

The indicators of natural increase in the CIS countries. As it's in the Annex 4 only five countries did not encounter natural growth issues amongst the CIS countries in 2016. In Tajikistan the natural growth formed $25 \%$ (promile),which is 1.7 times higher rate compared to 2000 . Kyrgyzstan had 22\%o, with 1.7 increase compared to 2000 . Uzbekistan had $18 \%$ with 1.1 increase compared 2000, whereas Kazakhstan had $15 \%$, with 3.2 increase and Azerbaijan had $11 \%$ with 1.2 increase. According to the data of 2016, Armenia registered natural growth but it was only $4.1 \%$, and the growth was 1.5 times more than in 2000. In Belarus, Moldova and Russia the natural growth indicator was zero. In 2000 the mentioned countries had negative indicator (natural decrease) which means that they have a positive change throughout the next years. However, these countries are far from competing with Tajikistan, Kyrgyzstan, Uzbekistan, Kazakhstan and Azerbaijan in terms of natural growth indicators. The lowest results were registered in Ukraine, where the coefficient formed only $-4 \%$. 


\section{CONCLUSIONS}

Analyzing the pension systems of CIS countries the study found that even the countries that preferred to preserve the classical distributive pension system had to perform parametric reforms throughout time. Those reforms included raising the retirement age and the number of work experience years, granting the right to pension. However, these are temporary solutions for the existing issues and they cannot prevent the worsening of the situation. The results of the comparative analysis of replacement and load rates of pension systems of the CIS countries display that the replacement rates of the countries preserving the distributive pension system could not reserve the minimum threshold established by ILO and have showed a tendency to decline. The pension system load in the countries preserving distributive pension system has shown tendency to decline besides Azerbaijan. This means that the pension load was distributed to lesser number of employed citizens. Consequently, the current demographic challenges led to parametric reforms in the legislation of the pension system, considering the expected increase in the average life expectancy.

The remaining CIS countries that preferred multi-pillar pension system, meaning they completed the state distributive pension system through mandatory accumulative component, aim to provide pension to elderly people through multiple sources. At the same time they want to increase the compensation indicators and to alleviate the burden on the state budget in the funding of pensions.

There are no apparent positive differences in terms of pension adequacy and system stability in the distributive or pay-as-you-go pension system and cumulative pension system countries, as the countries that introduced cumulative component, except for Kazakhstan, have invested in the second degree in recent years and can assess the effectiveness of the cumulative system only when retirees will get a retirement pension not only from the distribution component, but also from the cumulative component. 


\section{References}

Barr, N. (2002). Reforming Pensions: Myths, Truths, And Policy Choices, 55 International Social Security Review3, pp.7-22.

Catala, n, M. (2004). Pension Funds And Corporate Governance In Developing Countries: What Do We Know And What Do We Need To Know? Journal Of Pension Economics And Finance, 3(02), pp.197-232.

Mauricio, S. (2007). The Chilean Pension Reform:25 Years Later, Pensions: International Journal, March, pp.25-28.

Murphy, P., \& Musalem, A. (2004). Pension Funds and National Saving. Policy Research Working Papers. The World Bank, pp.4-38.

Raddatz, C., \& Schmukler, S. (2008).Pension Funds And Capital Market Development. How Much Bang For The Buck? Policy Research Working Paper; N 4787, Washington, DC: World Bank.

Torre, A., \& Schmukler, S. (2007). Emerging Capital Markets And Globalization. The Latin American Experience. A Co publication of Stanford Economics And Finance, An Imprint Of Stanford University Press, And The World Bank.

Yermo, J. (2005). Pension Reform And Capital Market Development. Office Of The Chief Economist, Latin America And Caribbean Region, The World Bank Background Paper For Regional Study On Social Security Reform. Background Paper For Regional Study On Social Security Reform, OECD, pp. 2-55.

\section{Websites visited}

http://apsf.ru/Izdaniya/Vestnik_MAPSF_2017(19).pdf

http://egov.kz/cms/ru/articles/pensionnaya_sistema

http://lex.uz/pages/GetAct.aspx?lact_id=112312

http://nafaka.tj/ru/qonunho/qonun-12-01-2010-595

http://nafaka.tj/ru/qonunho/qonun-19-03-2013-955

http://pensionreform.ru/59709)

http://socfond.kg/ru/citizens/9-Struktura-piensionnoi-sistiemy-KR.html

http://soczaschita-volkovysk.gov.by/index.php/ru/otdel-pensij-i-posobij/

dokumentatsiya/555-zakon-o-pensionnom-obespechenii-ot-13-yanvarya-2017-goda

http://turkmenistan.gov.tm/?id=2752

http://www.ilo.org/dyn/normlex/en/f?p=NORMLEXPUB:12100:0::NO::P12100_INSTRUMENT_ID:312247

http://www.pfrf.ru/grazdanam/pensions/kak_form_bud_pens/

http://www.pfu.gov.ua/pfu/control/uk/index

http://www.ssss.am/arm/pension-reforms/projects/ 
Annex-1

The ratio of numberof pensioners to total population (1992-2016)

\begin{tabular}{|c|c|c|c|c|c|c|c|c|c|c|}
\hline Year & 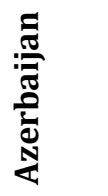 & 永 & $\frac{\pi}{\frac{\pi}{0}}$ & 苟 & 营 & 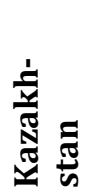 & 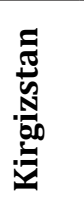 & 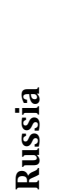 & 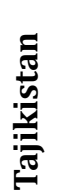 & 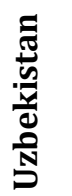 \\
\hline 1992 & 14.8 & 24 & 20.3 & 27.4 & 18 & 17.1 & 14.2 & 23.8 & 9.9 & 12.5 \\
\hline 1993 & 16.9 & 24.4 & 20.8 & 27.9 & 18.6 & 18.4 & 14.2 & 24.3 & 10.9 & 12.7 \\
\hline 1994 & 19.9 & 24.6 & 21.2 & 28.1 & 18.7 & 18 & 13.6 & 24.7 & 10.4 & 12.3 \\
\hline 1995 & 16.1 & 24.8 & 18.2 & 27.2 & 19.5 & 18.2 & 13.6 & 25 & 10.1 & 12.3 \\
\hline 1996 & 16.2 & 25 & 17.6 & 27.4 & 19 & 18.6 & 13.4 & 25.5 & 9.7 & 12.5 \\
\hline 1997 & 15.5 & 25.2 & 17.6 & 27.8 & 18.4 & 18.1 & 13.3 & 25.8 & 9.4 & 12.5 \\
\hline 1998 & 14.9 & 25.1 & 20.9 & 27.9 & 18 & 17.9 & 13.2 & 26 & 9.4 & 12.5 \\
\hline 1999 & 15.2 & 25.2 & 20.7 & 28.2 & 17.8 & 17.5 & 12.9 & 26 & 9.3 & 12.7 \\
\hline 2000 & 15.2 & 25 & 19.9 & 28.2 & 17.5 & 17.3 & 12.4 & 26.1 & 9.2 & 12.6 \\
\hline 2001 & 15.4 & 24.9 & 19.2 & 28.4 & 17.3 & 16.7 & 12.3 & 26.4 & 8.8 & 12.9 \\
\hline 2002 & 15.7 & 24.8 & 18.5 & 28.6 & 17 & 16.3 & 12.3 & 26.4 & 8.6 & - \\
\hline 2003 & 16 & 24.9 & 17.8 & 28.8 & 17 & 16.1 & 11.9 & 26.3 & 8.2 & - \\
\hline 2004 & 16.5 & 25 & 17.6 & 28.5 & 16.9 & 15.9 & 11.1 & 26.5 & 7.9 & 12.5 \\
\hline 2005 & 16.7 & 24.9 & 17.5 & 28.6 & 16.7 & 15.7 & 11.6 & 26.7 & 7.6 & 12.4 \\
\hline 2006 & 14.3 & 25.2 & 17.5 & 28.5 & 16.5 & 15.5 & 11.4 & 26.8 & 7.6 & - \\
\hline 2007 & 14.4 & 25.2 & 17.4 & 28.4 & 16.3 & 15.1 & 11.3 & 27.1 & 7.5 & - \\
\hline 2008 & 14.5 & 25.2 & 17.5 & 28.4 & 16.4 & 15 & 12.2 & 27.2 & 7.5 & - \\
\hline 2009 & 14.7 & 25.8 & 17.5 & 28.5 & 16.3 & 15 & 11.9 & 27.5 & 7.5 & - \\
\hline 2010 & 14.2 & 26 & 17.6 & 30.1 & 15.9 & 14.6 & 9.7 & 27.8 & 7.4 & 10.4 \\
\hline 2011 & 13.8 & 26.2 & 17.9 & 30.4 & 15.5 & 14.5 & 9.8 & 28.1 & 7.6 & 10 \\
\hline 2012 & 13.6 & 26.5 & 18.3 & 30.1 & 16.8 & 14.4 & 10 & 28.3 & 7.5 & 9.7 \\
\hline 2013 & 13.5 & 26.8 & 18.5 & 29.9 & 17.1 & 14.9 & 10.1 & 28.6 & 7.5 & 9.6 \\
\hline 2014 & 13.5 & 27 & 18.8 & 28.4 & 17.3 & 14.9 & 10 & 28.3 & 7.2 & 9.5 \\
\hline 2015 & 13.4 & 27.3 & 19.1 & 28.9 & 17.5 & 15 & 10 & 29.2 & 7.2 & 9.6 \\
\hline 2016 & 13.4 & 27.5 & 19.1 & 28.1 & 17.9 & 15.4 & 10 & 29.4 & 7.4 & 9.6 \\
\hline Mean & 15.1 & 25.5 & 18.7 & 28.5 & 17.4 & 16.2 & 11.9 & 26.7 & 8.5 & 11.5 \\
\hline SD & 1.4 & 0.9 & 1.2 & 0.8 & 1.0 & 1.4 & 1.4 & 1.4 & 1.1 & 1.4 \\
\hline
\end{tabular}

Source: CIS countries' statistical data 1992-2016

SD: Standard Deviation 
Annex-2

The indicator of the pension system load of the CIS countries from 1992-2016

\begin{tabular}{|c|c|c|c|c|c|c|c|c|c|c|c|c|}
\hline & 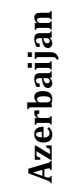 & 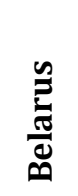 & $\frac{\frac{\pi}{2}}{\frac{0}{0}}$ & 氙 & & 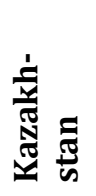 & 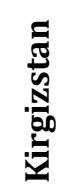 & 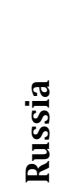 & 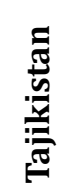 & 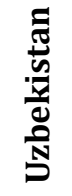 & $\underset{\Sigma}{\mathbb{J}}$ & คे \\
\hline 1992 & 3.40 & 2.00 & 2.30 & 1.70 & 2.40 & 2.70 & 2.90 & 2.00 & 3.50 & 3.10 & 2.60 & 0.59 \\
\hline 1993 & 3.00 & 1.90 & 1.80 & 1.70 & 2.40 & 2.30 & 2.60 & 1.90 & 3.00 & 3.00 & 2.36 & 0.50 \\
\hline 1994 & 2.80 & 1.90 & 1.80 & 1.60 & 2.30 & 2.20 & 2.70 & 1.80 & 3.20 & 3.10 & 2.34 & 0.55 \\
\hline 1995 & 2.90 & 1.70 & 2.10 & 1.70 & 2.30 & 2.20 & 2.70 & 1.70 & 3.30 & 3.00 & 2.36 & 0.56 \\
\hline 1996 & 3.00 & 1.70 & 2.20 & 1.70 & 2.40 & 2.20 & 2.70 & 1.60 & 3.10 & 3.00 & 2.36 & 0.55 \\
\hline 1997 & 3.10 & 1.70 & 2.20 & 1.70 & 2.30 & 2.30 & 2.70 & 1.50 & 3.30 & 3.00 & 2.38 & 0.60 \\
\hline 1998 & 3.10 & 1.80 & 2.10 & 1.60 & 2.30 & 2.30 & 2.80 & 1.60 & 3.10 & 3.00 & 2.37 & 0.57 \\
\hline 1999 & 3.10 & 1.80 & 2.00 & 1.40 & 2.30 & 2.30 & 2.90 & 1.70 & 3.10 & 2.90 & 2.35 & 0.59 \\
\hline 2000 & 3.00 & 1.80 & 2.10 & 1.50 & 2.30 & 2.40 & 3.00 & 1.70 & 3.30 & 2.90 & 2.40 & 0.59 \\
\hline 2001 & 2.90 & 1.80 & 2.20 & 1.40 & 2.30 & 2.70 & 3.10 & 1.70 & 3.40 & 2.90 & 2.44 & 0.63 \\
\hline 2002 & 2.90 & 1.80 & 2.30 & 1.50 & 2.00 & 2.80 & 3.30 & 1.80 & 3.40 & 2.90 & 2.47 & 0.64 \\
\hline 2003 & 2.80 & 1.80 & 2.10 & 1.50 & 2.00 & 2.90 & 3.30 & 1.80 & 3.50 & 3.00 & 2.47 & 0.67 \\
\hline 2004 & 2.80 & 1.80 & 2.10 & 1.50 & 2.00 & 3.00 & 3.30 & 1.80 & 4.00 & 3.00 & 2.53 & 0.77 \\
\hline 2005 & 2.80 & 1.80 & 2.10 & 1.60 & 2.10 & 3.10 & 3.50 & 1.80 & 4.10 & 3.20 & 2.61 & 0.81 \\
\hline 2006 & 3.30 & 1.80 & 2.00 & 1.60 & 2.10 & 3.20 & 3.60 & 1.90 & 4.10 & 3.20 & 2.68 & 0.84 \\
\hline 2007 & 3.20 & 1.80 & 2.00 & 1.60 & 2.10 & 3.30 & 3.70 & 1.80 & 4.10 & 3.40 & 2.70 & 0.88 \\
\hline 2008 & 3.20 & 1.80 & 1.90 & 1.60 & 2.30 & 3.40 & 3.50 & 1.80 & 4.00 & 3.50 & 2.70 & 0.86 \\
\hline 2009 & 3.10 & 1.90 & 1.90 & 1.50 & 2.20 & 3.30 & 3.50 & 1.80 & 4.00 & 3.50 & 2.67 & 0.85 \\
\hline 2010 & 3.40 & 1.90 & 1.80 & 1.50 & 2.30 & 3.40 & 4.20 & 1.80 & 4.00 & 3.80 & 2.81 & 0.99 \\
\hline 2011 & 3.40 & 1.90 & 1.80 & 1.50 & 2.30 & 3.40 & 4.20 & 1.80 & 3.80 & 4.00 & 2.81 & 0.99 \\
\hline 2012 & 3.50 & 1.80 & 1.80 & 1.50 & 2.30 & 3.40 & 4.00 & 1.80 & 3.80 & 4.20 & 2.81 & 1.01 \\
\hline 2013 & 3.50 & 1.80 & 1.80 & 1.50 & 2.30 & 3.30 & 3.90 & 1.70 & 3.80 & 4.30 & 2.79 & 1.02 \\
\hline 2014 & 3.60 & 1.80 & 1.80 & 1.50 & 2.20 & 3.30 & 3.90 & 1.70 & 3.90 & 4.20 & 2.79 & 1.03 \\
\hline 2015 & 3.60 & 1.70 & 1.80 & 1.30 & 2.00 & 3.20 & 3.90 & 1.70 & 3.80 & 4.30 & 2.73 & 1.07 \\
\hline 2016 & 3.60 & 1.70 & 1.80 & 1.40 & 1.90 & 3.10 & 3.80 & 1.70 & 3.70 & 4.30 & 2.70 & 1.04 \\
\hline
\end{tabular}

Source: CIS countries' statistical data 1992-2016

SD: Standard Deviation 